\title{
EVALUASI PENERAPAN PROTOKOL KESEHATAN DALAM MENCEGAH PENULARAN COVID-19 DI GEREJA-GEREJA WILAYAH KECAMATAN GUDO KABUPATEN JOMBANG TAHUN 2021
}

Lois Putu Primawidani*, Ferry Kriswandana, Deddy Adam

Jurusan Kesehatan Lingkungan Poltekkes Kemenkes Surabaya *Email korespondensi: primawii22@gmail.com

\begin{abstract}
In March 2020 the government determined that the COVID-19 outbreak was a national disaster that spread through splashes, so gatherings of large numbers of people could increase the risk of spreading COVID-19. The church is a place for Christians to carry out religious activities. During this activity, there was interaction between congregations that could increase the potential for the spread of COVID-19. The purpose of this study was to describe and evaluate the application of health protocols in preventing the transmission of COVID-19 in churches in the Gudo District, Jombang Regency in 2021.

This study uses a descriptive observational method. The variables of this research are socialization and education of COVID-19 health protocols, use of masks, hand washing facilities or hand sanitizers, disinfection, social distancing systems, thermoguns, restrictions on the number of congregations and duration of worship, as well as air circulation and floor types. Data collection used observations and interviews to describe the implementation of the COVID-19 health protocol in seven churches in Gudo District, Jombang Regency. Data analysis in this study is to collect data, process and compile, then presented in tabulation then each variable is analyzed descriptively.

Observation results show that all churches get the Good category with a minimum score of $76.92 \%$. The results of the interview show that the manager has facilitated the congregation in implementing the COVID-19 health protocol.

The conclusion from this research is that the implementation of the COVID-19 health protocol is not optimally implemented, namely socialization and education of the COVID19 health protocol and measuring body temperature. Suggestions for other researchers who want to continue this research are researching the implementation of the COVID-19 health protocol in places of worship using quantitative research methods.
\end{abstract}

Keywords: COVID-19, Health protocols, Church

\section{PENDAHULUAN}

Tempat-tempat umum (TTU) merupakan tempat dimana orang berkumpul dan berkegiatan, baik kegiatan yang mendadak maupun kegiatan yang rutin dilakukan setiap hari. Pada TTU perlu dilakukan upaya pengawasan guna memastikan bahwa kualitas kesehatan di TTU telah memenuhi syarat. WHO menyatakan bahwa sanitasi adalah upaya pengawasan faktor lingkungan fisik yang membawa pengaruh bagi kehidupan manusia. Jadi sanitasi TTU merupakan upaya pengawasan lingkungan dan pencegahan terjadinya dampak negatif di TTU yang berkaitan dengan faktor tempat, fasilitas atau sarana, serta sumber daya manusia yang tidak memenuhi syarat. (APTKLI, 2019)
Tahun 2020 menjadi tahun yang berat bagi Indonesia. Hal ini karena munculnya kasus COVID-19 di Indonesia pada Bulan Maret 2020. Pada tanggal 14 Maret 2020 Pemerintah telah menetapkan bahwa wabah virus corona merupakan Bencana Nasional. Hal itu diutarakan oleh Kepala Badan Nasional Penanggulangan Bencana, Doni Monardo. dr. Achmad Yurianto selaku juru bicara pemerintah untuk COVID-19 mengatakan bahwa menurut UndangUndang Bencana nomor 24 tahun 2007, bencana dibagi menjadi tiga yaitu bencana alam, bencana non alam, dan bencana sosial. Bencana non alam salah satunya adalah wabah atau pandemi. Sehingga Indonesia termasuk dalam status tanggap darurat bencana non alam yaitu pandemi COVID-19. Virus 
COVID-19 merupakan virus yang dapat menyebabkan kematian. Oleh sebab itu, sangat perlu digalakkan peraturan untuk mencegah dan mengurangi risiko penularan COVID-19. Menurut Keputusan Menteri Kesehatan Republik Indonesia Nomor 382/2020 Tentang Protokol Kesehatan bagi Masyarakat di Tempat dan Fasilitas Umum Dalam Rangka Pencegahan dan Pengendalian Corona Virus Disease 2019 (COVID-19), tempat dan fasilitas umum memiliki risiko cukup tinggi terhadap terjadinya penularan COVID-19 dikarenakan terjadi aktivitas dan perkumpulan banyak orang.

Penularan atau penyebaran virus corona seperti yang sudah diketahui adalah melalui percikan atau droplet yang keluar dari mulut dan hidung, sehingga perkumpulan banyak orang dapat menambah risiko penyebaran virus corona. Perkumpulan yang dilakukan saat kegiatan keagamaan dapat menimbulkan adanya potensi penyebaran dan penularan COVID-19, sehingga penting diterapkan protokol kesehatan yang telah ditetapkan dalam Keputusan Menteri Kesehatan dalam upaya mencegah dan menganggulangi penyebaran dan penularan COVID-19 diantaranya yaitu memakai masker, rajin mencuci tangan dengan sabun, menjaga jarak minimal satu meter, dan meningkatkan daya tahan tubuh serta menerapkan Perilaku Hidup Bersih dan Sehat. (Keputusan Menteri Kesehatan Republik Indonesia Nomor 382/2020)

$$
\text { Gereja menjadi tempat }
$$

berkumpulnya para umat kristiani untuk melakukan kegiatan keagamaan. Dalam kegiatan tersebut tentu terjadi interaksi antara jemaat satu dengan jemaat lain yang dapat menjadi potensi penyebaran COVID-19. Selama pandemi COVID-19, terjadi banyak perubahan di dalam gereja dan sekitarnya, terutama dalam hal sosialisasi dan edukasi tentang COVID-19 serta penambahan fasilitas sanitasi seperti yang sudah dianjurkan oleh Kementerian Kesehatan. Seperti yang dijelaskan oleh Muslikha dan Friska (2018) dalam jurnalnya yang berjudul Implementasi Sanitasi Masjid di Wilayah Kecamatan Wonocolo Kota Surabaya Ditinjau Dari Aspek Fasilitas Sanitasi, bahwa kurangnya kesadaran perilaku hidup bersih dan sehat serta kurangnya fasilitas sanitasi yang memadai, dapat menyebabkan penularan penyakit. Lailatul \& Khuzaifah (2020) mengakatakan bahwa kegiatan evaluasi penerapan protokol kesehatan COVID-19 memiliki tujuan untuk mengetahui dan mengategorikan pelaksanaan penerapan kebijakan tersebut.

Setiap gereja memiliki kebijakan masing-masing dalam mengupayakan kepatuhan terhadap penerapan protokol kesehatan COVID-19. Penelitian ini dilakukan di gereja-gereja terutama di Kecamatan Gudo Kabupaten Jombang. Menurut informasi dari Dinas Kesehatan Kabupaten Jombang, terhitung 27 Oktober 2020 pukul 14.00 WIB terdapat 5 pasien suspect COVID-19 di Kecamatan Gudo dari total 72 pasien suspect COVID19 di Kabupaten Jombang, dan terdapat 22 pasien positif COVID-19 di Kecamatan Gudo dari total 1.144 kasus positif COVID-19 di Kabupaten Jombang.

Penelitian ini bertujuan untuk menggambarkan penerapan protokol kesehatan dalam mencegah penularan COVID-19 di gereja-gereja di Kecamatan Gudo Kabupaten Jombang tahun 2021.

\section{METODE PENELITIAN}

Desain penelitian ini menggunakan metode observasional yang bersifat deskriptif dengan tujuan menggambarkan dan mengevaluasi penerapan protokol kesehatan COVID-19 di gereja-gereja di Kecamatan Gudo Kabupaten Jombang. Dengan begitu perlu dilakukan wawancara mendalam disertai pengisian lembar observasi untuk mengidentifikasi bagaimana penerapan protokol kesehatan COVID-19 di gereja-gereja wilayah tersebut.

Variabel penelitian ini adalah penerapan protokol kesehatan di rumah ibadah yang tercantum dalam Keputusan Menteri Kesehatan Nomor 382 Tahun 2020 dan Surat Edaran Kementerian Agama Nomor 15 Tahun 2020.

Penelitian ini menggunakan populasi gereja-gereja yang ada di Kecamatan Gudo Kabupaten Jombang pada tahun 2021 sebanyak 7 (tujuh) gereja. Sampel yang digunakan adalah seluruh gereja 
yang ada di Kecamatan Gudo Kabupaten Jombang namun sesuai dengan persetujuan antara peneliti dengan pengelola yaitu sebanyak 7 (tujuh) gereja.

Data yang diperoleh berupa data primer yaitu hasil pengisian lembar observasi dan hasil wawancara bersama pengelola gereja mengenai kondisi penerapan protokol kesehatan COVID-19 di gereja tersebut dan melakukan pengambilan data lain yang diperlukan seperti dokumentasi tempat yaitu gerejagereja yang digunakan untuk penelitian.

Data lengkap yang telah terkumpul akan diolah kemudian disusun dalam tabulasi dan dijelaskan dalam bentuk narasi untuk mempermudah analisis variabel yang diteliti secara deskriptif. Dalam mendeskripsikan hasil dari analisis data, dilakukan perhitungan dari pengisian lembar observasi terlebih dahulu untuk menentukan kategori baik, cukup, dan kurang.

\section{HASIL DAN PEMBAHASAN \\ Hasil dan Pembahasan Kepatuhan Pengelola Gereja}

Tabel 1

SOSIALISASI COVID-19 DAN EDUKASI PROTOKOL KESEHATAN COVID-19

DI GEREJA-GEREJA SE-KECAMATAN GUDO KABUPATEN JOMBANG TAHUN 2021

\begin{tabular}{ccc}
\hline Kode Gereja & Presentase $(\%)$ & Kategori \\
\hline 1 & 66,67 & Cukup \\
\hline 2 & 83,34 & Baik \\
\hline 3 & 83,34 & Baik \\
\hline 4 & 50 & Kurang \\
\hline 5 & 50 & Kurang \\
\hline 6 & 66,67 & Cukup \\
\hline 7 & 83,34 & Baik \\
\hline
\end{tabular}

Berdasarkan tujuh gereja yang diteliti, pada variabel Sosialisasi COVID-19 dan edukasi Protokol Kesehatan COVID19 terdapat dua gereja memperoleh presentase $50 \%$ yang berarti kategorinya Kurang. Kemudian terdapat dua gereja dengan presentase $66,67 \%$ yang berarti termasuk kategori Cukup. Tiga gereja lainnya hampir memenuhi semua komponen yaitu memperoleh presentase $83,34 \%$ dengan kategori Baik.

Kepmenkes Republik Indonesia Nomor 382 Tahun 2020 menyatakan bahwa komponen-komponen pada

Tujuh gereja yang dilakukan observasi, pada variabel fasilitas cuci tangan atau handsanitizer semua gereja memperoleh kategori Baik dengan presentase $100 \%$. Hal tersebut berarti semua pengelola gereja sudah menyediakan fasilitas cuci tangan.

Lailatul dan Khuzaifah (2020) menyatakan bahwa menjaga kebersihan tangan merupakan salah satu upaya agar tubuh terhindar dari COVID-19 yaitu dengan cara mencuci tangan dengan variabel ini merupakan upaya yang perlu dilakukan untuk melakukan pencegahan dan pengendalian risiko penularan COVID-19. Berdasarkan fakta tersebut, dapat diketahui bahwa pengelola seluruh gereja di Kecamatan Gudo Kabupaten Jombang berupaya melaksanakan sosialisasi COVID-19 dan edukasi protokol kesehatan COVID-19. Namun pelaksanaan sosialisasi dan edukasi tersebut belum maksimal dikarenakan terdapat 2 gereja yang masuk dalam kategori Cukup dan 2 gereja kategori Kurang.

sabun, digosok minimal selama 20 detik dan dibilas air mengalir. Apabila tidak terdapat fasilitas tersebut dapat menggunakan handsanitizer/handrub dengan kandungan alkohol $70-80 \%$. Fasilitas cuci tangan dengan sabun atau handsanitizer yang harus disediakan di tempat ibadah telah tertera dalam Kepmenkes Republik Indonesia Nomor 382 Tahun 2020 dan Surat Edaran Menteri Agama Republik Indonesia Nomor 15 Tahun 2020. 
Tujuh gereja yang dilakukan penelitian, pada variabel desinfeksi semua gereja mendapatkan presentase sebesar $100 \%$ dan kategori Baik. Hal tersebut menunjukkan bahwa pengelola telah melaksanakan desinfeksi secara rutin setiap sebelum dan sesudah kegiatan peribadatan.

Menurut Kepmenkes Republik Indonesia Nomor 382 Tahun 2020 dan
Surat Edaran Menteri Agama Republik Indonesia Nomor 15 Tahun 2020, penyemprotan cairan desinfektan sangat penting dilakukan pada tempat dan fasilitas umum. Athena dkk (2020) menuliskan bahwa salah satu upaya mencegah penularan COVID-19 di fasilitas umum adalah dengan melakukan desinfeksi.

Tabel 2

THERMOGUN DI GEREJA-GEREJA SE-KECAMATAN GUDO KABUPATEN JOMBANG TAHUN 2021

\begin{tabular}{ccc}
\hline Kode Gereja & Presentase $(\%)$ & Kategori \\
\hline 1 & 50 & Kurang \\
\hline 2 & 100 & Baik \\
\hline 3 & 100 & Baik \\
\hline 4 & 50 & Kurang \\
\hline 5 & 50 & Kurang \\
\hline 6 & 100 & Baik \\
\hline 7 & 100 & Baik \\
\hline
\end{tabular}

Menurut tabel di atas, disimpulkan bahwa pada variabel thermogun yang diobservasi pada tujuh gereja, tiga gereja dengan presentase $50 \%$ sehingga mendapatkan kategori Kurang. Kemudian empat gereja memperoleh kategori Baik dengan presentase $100 \%$. Dalam hal ini terdapat pengelola yang kurang melakukan pemeriksaan suhu tubuh setiap sebelum kegiatan peribadatan.

Dalam Kepmenkes Republik Indonesia Nomor 382 Tahun 2020 dan Surat Edaran Menteri Agama Republik Indonesia Nomor 15 Tahun 2020

Pembatasan jumlah jemaat (maksimal $20 \%$ dari kapasitas ruang) dan durasi ibadah yang diteliti di tujuh gereja, semua gereja memeproleh kategori Baik dengan presentase $100 \%$. Pengelola melakukan pembatasan antara lain dengan cara mengurangi jumlah tempat duduk dan melakukan system pendaftaran untuk kehadiran di gereja.

Sirkulasi udara dan jenis lantai yang diteliti di tujuh gereja, semua memperoleh skor maksimal. Dengan demikian dapat diketahui bahwa semua gereja memperoleh presentase $100 \%$ dan termasuk dalam kategori Baik. Terdapat jendela dan lubang-lubang angin yang cukup sehingga terjadi sirkulasi udara dikatakan bahwa pemeriksaan suhu tubuh jemaat sebelum masuk ke tempat ibadah sangat penting sebagai bentuk pencegahan penularan COVID-19. Achlison (2020) menyebutkan bahwa salah satu langkah pencegahan penyebaran COVID-19 adalah dengan melakukan pemeriksaan suhu tubuh. Selain itu pemeriksaan suhu tubuh merupakan upaya untuk mendeteksi tanda-tanda awal COVID-19 supaya kontak langsung dapat dihindari. (Wulandari, 2020)

Berdasarkan pernyataan dalam Kepmenkes Republik Indonesia Nomor 382 Tahun 2020 dan Surat Edaran Menteri Agama Republik Indonesia Nomor 15 Tahun 2020, pembatasan jumlah jemaat dan pengurangan durasi ibadah dikatakan sebagai upaya pencegahan penularan COVID-19 di tempat ibadah.

yang baik. Lantai gereja terbuat dari keramik sehingga mudah dibersihkan.

Dalam Kepmenkes Republik Indonesia Nomor 382 Tahun 2020 dan Surat Edaran Menteri Agama Republik Indonesia Nomor 15 Tahun 2020, sirkulasi udara dan jenis lantai penting diperhatikan karena termasuk dalam 
upaya mencegah penularan COVID-19 yang diketahui menyebar melalui udara. Sirkulasi udara yang baik dan jenis lantai yang mudah dibersihkan dapat menekan penyebaran virus COVID-19.

\section{Hasil dan Pembahasan Kepatuhan Jemaat Gereja}

Dari tujuh gereja yang diteliti, semua gereja meraih kategori Baik dengan presentase $100 \%$ pada variabel penggunaan masker. Menurut Pinasti
(2020), salah satu upaya perlindungan diri dalam masa Pandemi COVID-19 adalah penggunaan masker. Masker tidak hanya berguna menjadi pelindung namun juga pencegah penularan COVID-19. Kepmenkes Republik Indonesia Nomor 382 Tahun 2020 dan Surat Edaran Menteri Agama Republik Indonesia Nomor 15 Tahun 2020 menyatakan bahwa pemakaian masker sangat penting dan wajib dilakukan ketika berada di tempat ibadah

Tabel 3

SISTEM JAGA JARAK DI GEREJA-GEREJA SE-KECAMATAN GUDO KABUPATEN JOMBANG TAHUN 2021

\begin{tabular}{ccc}
\hline Kode Gereja & Presentase $(\%)$ & Kategori \\
\hline 1 & 66,67 & Cukup \\
\hline 2 & 83,34 & Baik \\
\hline 3 & 83,34 & Baik \\
\hline 4 & 50 & Kurang \\
\hline 5 & 50 & Kurang \\
\hline 6 & 66,67 & Cukup \\
\hline 7 & 83,34 & Baik \\
\hline
\end{tabular}

Berdasarkan kategori yang ditampilkan diatas, dapat dilihat bahwa sistem jaga jarak yang diobservasi pada tujuh gereja, semua gereja meraih kategori Baik dengan presentase $100 \%$. Di dalam gereja tempat duduk diatur sedemikian rupa sehingga antara jemaat satu dengan jemaat lainnya berjarak 1 meter. Pengaturan jarak dilakukan dengan cara memisahkan tempat duduk atau memberi tanda pada pada tempat duduk.

Kepmenkes Republik Indonesia Nomor 382 Tahun 2020 dan Surat Edaran
Menteri Agama Republik Indonesia Nomor 15 Tahun 2020 menyatakan bahwa jaga jarak antar jemaat sangat penting agar pencegahan penularan COVID-19 dapat digalakkan. Pinasti (2020) menyebutkan bahwa jaga jarak atau social distancing memiliki tujuan agar mengurangi interaksi antara masyarakat dengan beberapa warga yang memiliki kemungkinan terinfeksi COVID-19. Organisasi Kesehatan Dunia atau WHO pada tahun 2020 menyatakan bahwa menjaga jarak dapat dilakukan sejauh 1 meter atau 3 kaki dengan orang lain.

\section{Hasil dan Pembahasan Keseluruhan Observasi}

Tabel 4

HASIL KESELURUHAN PENILAIAN LEMBAR OBSERVASI

\begin{tabular}{ccc}
\hline Observasi Gereja & Presentase $(\%)$ & Kategori \\
\hline 1 & 82,05 & Baik \\
\hline 2 & 94,87 & Baik \\
\hline 3 & 94,87 & Baik \\
\hline 4 & 76,92 & Baik \\
\hline 5 & 82,05 & Baik \\
\hline 6 & 89,74 & Baik \\
\hline 7 & 94,87 & Baik \\
\hline
\end{tabular}


Dari tabel tersebut dapat diketahui bahwa penerapan protokol kesehatan COVID-19 pada gereja-gereja di Kecamatan Gudo Kabupaten Jombang termasuk dalam ketegori "Baik". Skor tertinggi didapatkan oleh Gereja 2, 3, dan 7 yaitu sebesar $94,87 \%$. Skor terendah yaitu pada Gereja 4 sebesar 76,92\%.

\section{KESIMPULAN}

1. Pengelola gereja mematuhi penerapan protokol kesehatan COVID-19 sesuai dengan peraturan yang berlaku. Protokol kesehatan yang dilakukan sesuai yang tercantum dalam Keputusan Menteri Kesehatan Republik Indonesia Nomor 382 Tahun dan Surat Edaran Menteri Agama Republik Indonesia Nomor 15 Tahun 2020. Namun dalam beberapa hal seperti sosialisasi dan edukasi dengan cara memasang banner/poster

pelaksanaan protokol kesehatan COVID-19 dan pengukuran suhu tubuh jemaat sebelum ibadah masih belum dilaksanakan secara maksimal.

2. Jemaat gereja mematuhi dan menjalankan arahan dari pengelola gereja dalam menerapkan protokol kesehatan COVID-19. Protokol kesehatan yang dilakukan sesuai aturan yang tercantum dalam Kepmenkes Republik Indonesia Nomor 382 Tahun 2020 dan Surat Edaran Menteri Agama Republik Indonesia Nomor 15 Tahun 2020.

\section{SARAN}

1. Bagi Jemaat Gereja

a. Jemaat gereja sebaiknya bersedia untuk ikut andil apabila pengelola gereja menunjuk untuk menjadi pengawas protokol kesehatan COVID-19.

b. Jemaat gereja sebaiknya aktif dalam memberikan kritik dan saran kepada pengelola gereja apabila terdapat protokol kesehatan COVID-19 yang kurang berjalan dengan baik.
2. Bagi Pengelola Gereja

a. Pengelola gereja sebaiknya memasang banner/poster tentang protokol kesehatan COVID-19 pada titik-titik yang mudah dijangkau dan dilihat jemaat gereja.

b. Pengelola gereja sebaiknya menunjuk beberapa orang jemaat untuk menjadi pengawas protokol kesehatan COVID-19.

c. Pengelola gereja sebaiknya tetap melakukan pengukuran suhu tubuh jemaat sebelum masuk ke gereja.

3. Bagi Peneliti Lain

Peneliti lain sebaiknya melakukan penelitian lanjutan terkait penerapan protokol kesehatan COVID-19 di tempat ibadah menggunakan metode deskriptif analitik.

\section{DAFTAR PUSTAKA}

Achlison, U., 2020. Analisis Implementasi Pengukuran Suhu Tubuh Manusia dalam Pandemi Covid-19 di Indonesia. Jurnal Ilmiah Komputer Grafis, 13(2), pp. 102-106.

APTKLI, 2019. Kesehatan Lingkungan Teori dan Aplikasi. Jakarta: Penerbit Buku Kedokteran EGC.

Anon., 2020. Data COVID-19 Kabupaten Jombang.

Athena, Laelasari, E. \& Puspita, T., 2020. Pelaksanaan Desinfeksi dalam Pencegahan Penularan COVID-19 dan Potensi Risiko Terhadap Kesehatan di Indonesia. Jurnal Ekologi Kesehatan, Juni, 19(1), pp. 1-20.

Keputusan Menteri Kesehatan Republik Indonesia Nomor HK.01.07/MENKES/382/2020, 2020. Protokol Kesehatan bagi Masyarakat di Tempat dan Fasilitas Umum Dalam Rangka Pencegahan dan Pengendalian Corona Virus Disease 2019 (COVID-19). Jakarta: s.n.

Lailatul, M. F. \& Khuzaifah, 2020. Evaluasi Penerapan Protokol Kesehatan Pencegahan Penyebaran COVID-19 dalam Pembelajaran Praktik di Laboratorium Program Studi 
Kebidanan Poso. Jurnal Pengelolaan Laboratorium Pendidikan.

Muslikha, N. R. \& Friska, A., 2018. Implementasi Sanitasi Masjid di Wilayah Kecamatan Wonocolo Kota Surabaya Ditinjau dari Aspek Fasilitas Sanitasi. In Proceeding National Seminar GERMAS 2018, 1(1).

Pinasti, F. D. A., 2020. Analisis Dampak Pandemi Corona Virus Terhadap Tingkat Kesadaran Masyarakat dalam Penerapan Protokol Kesehatan. Wellness and Healthy Magazine, 2(2), pp. 237-249.

Surat Edaran Menteri Agama Republik Indonesia No. 15 Tahun 2020, n.d. Panduan Penyelenggaraan Kegiatan Keagamaan di Rumah Ibadah Dalam Mewujudkan Masyarakat Produktif dan Aman COVID di Masa Pandemi. Jakarta: s.n.
WHO, 2020. Infection prevention and control during health care when novel coronavirus ( $\mathrm{nCoV}$ ) infection is suspected. Geneva: World Health Organization.

WHO, 2021. Coronavirus disease (COVID-19) pandemic.

Wulandari, R., 2020. Rancang Bangun Pengukur Suhu Tubuh Berbasis Arduino Sebagai Alat Deteksi Awal COVID-19. Prosiding SNFA (Seminar Nasional Fisika dan Aplikasinya) 2020, pp. 183-189. 